\title{
Value Chain Analysis of Head Cabbage: The Case of Kofele and Kore Districts in West Arsi Zone, Oromia National Regional State, Ethiopia
}

\author{
Beriso Bati \\ Department of Agricultural Economics, Adami Tulu Agricultural Research Centre, Adami Tulu, Ethiopia
}

\begin{abstract}
Cabbage is highly nutritious, and it is an economically important vegetable in Ethiopia and one of the most widely cultivated in West Arsi zone especially at Kofale and Kore districts. The study was aimed to analysis head cabbage value chain in Kofale and Kore districts with the specific objectives of identifying head cabbage value chain actors and examining the performance of actors in the chain in the study area. Data were collected from both primary and secondary sources. The primary data were generated by household survey using a pretested structured questionnaire and key informant interview using checklists. The data were collected from 120 farmers, 50 traders and 50 consumers and analyzed using STATA software. Value chain actors of head cabbage identified in the study area includes input suppliers, producers, rural collectors, brokers, wholesalers, retailers, and consumers. Five market channels were identified. The highest total gross margins were $79.28 \%$ in channel II. The highest gross marketing margin of producers markets channels are $85.56 \%$ in channel IV. From total quantity of head cabbage produced only $33.48 \%$ supplied to the market in the study area. Policy implications drawn from the study findings include the need to improve farmers' knowledge and experience on head cabbage production and marketing, encouraging adult education through extension service, improving land allocated for head cabbage, improving productivity and volume sales of head cabbage, improving market information access, expanding accessibility of market infrastructure and strengthening supportive institutions like credit access are recommended. In addition to this the study suggests that it shall be better to improve the farmers' market margins from collectors and wholesalers by strengthening farmers-traders linkage through reducing brokers' exploitation and solving related production and marketing problems in the study area.
\end{abstract}

Keywords: Value chain analysis, Head cabbage, Marketing margin, Market Performance, Ordinary least square model, and Kofele and Kore districts.

DOI: $10.7176 / \mathrm{JAAS} / 52-05$

\section{Introduction}

Agriculture is central to Africa's agenda, and efforts have made to link production with agribusiness for better growth in the sector. Now days, it earns an average of 24 per cent of its annual growth from its farmers and their crops value chains reveal common and well-known constraints, such as poor infrastructure; fragmented and risky markets; poorly functioning input markets; difficulties accessing land, water, and finance; and inadequate skills and technology. More revealing, however, is the big differences across value chains (World Bank, 2013).

As other leafy vegetables, cabbage is highly nutritious vegetable and has so many health benefits. It is rich in phyto-nutrient anti-oxidants that are powerful oxidants and known to help protect against breast, colon, and prostate cancers and help reduce LDL or "bad cholesterol" levels in the blood. Moreover, fresh cabbage is an excellent source of natural antioxidant, vitamin $\mathrm{C}$ that helps the body develop resistance against infectious agents and scavenge harmful, pro-inflammatory free radicals (Umesh Rudrappa, 2014).

Vegetable production is becoming an increasingly important activity in the agricultural sector of the country mainly due to increased emphasis of the government on the commercialization of smallholder farmers (Hailegiorgis and Hagos, 2016). Integrating vegetable production into a farming system has contributes substantially to the Ethiopia's economy in terms of food and nutrition security as the vegetables complement stable foods for a balanced diet by providing vitamins and minerals (Bezabih et al., 2015). Head cabbage is one of economically important vegetables in the country which grows best under cool conditions. According to CSA (2014), annual head cabbage production (in quintal) and area under production (in hectare) has increased by about 16 and 30 percent, respectively, from 2012/13 to 2013/14. Agriculture and Rural Development office of Kofele and Kore districts (OoARD, 2013; OoARD, 2013) shows that head cabbage is widely produced and marketed in Kofale and Kore districts of West Arsi Zone, Oromia Regional State. The significantly increasing vegetable production in general and head cabbage in particular indicates that smallholders may have better surplus for market.

Despite the increasing importance of vegetables in the country as well as in the study area, the development of horticulture in general and vegetable production and marketing in Ethiopia in particular is constrained by a number of factors: Policy implementation gap, inadequate vegetable seed regulatory frameworks, inadequate quality control and certification mechanisms, limited public institutional capacity and capability supporting 
efficient and regular vegetable seed supply, inefficient seed importation and distribution system, high postharvest losses, high incidence of diseases and insect pests, poor vegetable marketing and value chain development and weak linkage and integration among stakeholders (Bezabih et al., 2014).

Despite the production potentials and importance of head cabbage crop for the country as well as the study area, there has been limited performance of farmers in head cabbage marketing. The factors governing head cabbage producers supply to the market are not well studied and appropriate policy options need to get locationspecific information to solve inherent problems. This study tries to fill the gap by providing location-specific and timely information on smallholder farmers' head cabbage supply to the markets.

The development and upgrading of the value chains is an important agenda for the government, companies and other institutions. Entry into higher value markets (also global markets) requires an understanding of the requirements and dynamic forces within the value chain (Baker, 2006). Understanding of the existing vegetables inputs supply systems, production and marketing systems of vegetables is important for developing well organized value chain development in the study area.

Even though some related studies were carried out in different regions of the country, such study that provides empirical evidence for improving the production and marketing of head cabbage has not been undertaken in the study area. Therefore, there is a strong need to make value chain analysis to identify head cabbage value chain and examine the performance of actors in the chain, and to identify the determinants of quantity of head cabbage supplied to the market in the study areas.

\subsection{Objectives of the Study}

$\square$ To identify head cabbage value chain actors, their respective roles and to draw up value chain map of in the study area.

$\square$ To analyze respective marketing costs and margins across market channels

\section{Research Methodology}

\subsection{Description of the study area}

This study was carried out in Kofale and Kore districts of West Arsi Zone, Oromia Regional State. West Arsi Zone is one of the 18 administrative zones under Oromia Regional State (the region accounting for about 34 percent of the country's total area) and it is divided into 12 districts (Fig. 1). Of the districts located in the zone, Kofale and Kore districts cover for about 5.3 (663 square kilometer) and 4.2 percent (533 square kilometer), respectively, of the zone's total area. According to CSA's (2013) population projection of the country, total population of these districts, respectively, is estimated to be 216,159 and 124,556 in 2014 with most population residing in rural areas.

According to the traditional classification system of climatic zones of Ethiopia cited in Deressa et al. (2010), agro-ecology of the study areas is dominantly highlands with altitude ranges from 2550 to 3150 meter above sea level (masl). The annual rainfall ranges between 1800 and $2700 \mathrm{~mm}$ with bi-modal rainfall distribution. The main rainy season, Ganna extends from June to September/October and short rainy season, arfasa, covers the time between March/April and May (OoARD, 2013a; OoARD, 2013b). The average daily minimum and maximum temperatures of both districts are $17-19^{\circ} \mathrm{C}$ and $22-23^{\circ} \mathrm{C}$, respectively.

The study districts are characterized by crop-livestock mixed farming system dominated by smallholders who integrate rain-fed crop cultivation and low input-output livestock production. Baseline information from Offices of Agriculture and Rural Development (OoARD, 2013a; OoARD, 2013b) indicates that agriculture, both crop and livestock production, is the major source of livelihood for most households (65 and 77 percent, respectively, in Kofale and Kore) followed by non-farm and off-farm activities. Crops including barley, wheat, maize, faba bean, pea and linseed are grown in these districts. Potato and head cabbage are also vegetables grown in the study areas for household consumption and income generation.

\subsection{Sources of data and method of collection}

Both primary and secondary data were used for this study. Secondary data sources include Kofele and Kore districts irrigation and development authority, Kofele and Kore districts Bureaus of Agriculture, District Trade and Market Development Office and its associated primary cooperatives and Central Statistical Authority (CSA), published and unpublished reports, bulletins, and websites. Both qualitative and quantitative data were collected and used for the study.

Primary data sources were smallholder farmers from six purposively selected kebele three each of districts and wholesalers, collectors, retailers and consumers. Primary data were collected using informal and formal surveys and key informants interviews. For informal survey Rapid Market Appraisal (RMA) technique like focus group discussion and key informant interview was used with checklists. The formal survey was undertaken through formal interviews with randomly selected farmers and purposively selected traders and consumers using a pre-tested structured questionnaire for each group. Before data collection, the questionnaire was pre-tested on 
four farmers to evaluate the appropriateness of the design, clarity and interpretation of the questions, relevance of the questions and to estimate time required for an interview. Subsequently, appropriate modifications and corrections were made on the questionnaire. The questionnaire covered different topics in order to capture relevant information related to the study objectives.

\subsection{Sampling Procedure}

A multi-stage sampling procedure was used to identify sample households for data collection. In the first stage, head cabbage producer kebeles were purposively identified in collaboration with concerned experts from district office of agriculture and development agents based on the intensity of head cabbage production and markets. The second stage involved random selection of three head cabbage producing kebeles from a list of the head cabbage producer kebeles in the districts namely, Shire kombolcha, Bole Hilensaa and Doda Dayu from Kore district and Wamagn Alkaso, Koma Bitacha and Germama from Kofale District. In the third stage, 120 head cabbage producer households were randomly selected from the total head cabbage producer households in the districts using Yamane (1967) sample size determination as follows:

$$
\mathrm{n}=\frac{\mathrm{N}}{1+\mathrm{N}(\mathrm{e})^{2}}
$$

Where, $\mathrm{n}=$ is the sample size of head cabbage producer households, $\mathrm{N}=$ total number of households producing head cabbage in the districts, $\mathrm{e}=$ level of precision considered $9 \%$.

Table 1: Sampling procedures of head cabbage producers

\begin{tabular}{|c|c|c|c|}
\hline No & Kebeles & $\begin{array}{l}\text { Total number of head cabbage producers } \\
(\mathrm{N}=10,000 \text { both districts })\end{array}$ & $\begin{array}{l}\text { Number of sampled } \\
\text { households }\end{array}$ \\
\hline 1 & Shire Kombolcha & 1667 & 20 \\
\hline 2 & Bolo Hinlensa & 1667 & 20 \\
\hline 3 & Doda Dayu & 1667 & 20 \\
\hline 4 & Wamagn Alkaso & 1667 & 20 \\
\hline 5 & Koma Bitacha & 1582 & 19 \\
\hline 6 & Germama & 1750 & 21 \\
\hline & Total & 10,000 & 120 \\
\hline
\end{tabular}

The sites for the trader surveys were market town in which a good of sample of head cabbage existed. On the basis of flow of head cabbage, four markets (Kofele, Kore, Shashemene and Hawassa) were selected as, the main head cabbage marketing sites for the study areas. Here sampling was the very difficult task due to absence of recorded list of population of traders and the opportunistic behavior of the traders. Hence a purposive sampling method was used to select wholesalers, rural collectors and retailers from specified markets. As a result, 50 head cabbage traders were selected for the purpose of the study. Furthermore, 50 consumers were interviewed from the above mentioned market district, which were selected randomly to obtain information related to consumers (Table 2).

Table 2: Sampling procedures of head cabbage traders and consumers

\begin{tabular}{llll}
\hline No & Name of market & Trader & Consumer \\
\hline 1 & Kofele & 14 & 13 \\
2 & Kore & 6 & 12 \\
3 & Shashemene & 21 & 15 \\
4 & Hawassa & 9 & 10 \\
\hline & Total & $\mathbf{5 0}$ & $\mathbf{5 0}$ \\
\hline
\end{tabular}

\subsection{Methods of data analysis}

Three types of data analysis, namely descriptive statistics, value chain analysis and econometric analysis were used for analyzing the data from producers, traders and consumers.

\section{Descriptive analysis}

Data were analyzed using STATA version 13, and the results were presented using descriptive statistics such as frequency, mean, standard deviation and percentage and inferential statistics such as t-test and chi-square were used to compare the mean differences between the two districts on different variables.

\section{Value chain analysis}

Value chain analysis is the process of breaking a chain into its constituent parts in order to better understand its structure and functioning. The analysis consists of identifying chain actors at each stage and discerning their functions and relationships; determining the chain governance, or leadership, to facilitate chain formation and strengthening; and identifying value adding activities in the chain and assigning costs and added value to each of those activities (UNIDO, 2009).

To understand the characteristics of the chain actors of head cabbage and the relationships exists between 
them, including the identification of all actors in the chain; the flow of product through the chain; the work features and the destination; information was obtained by conducting interviews, focus group discussion and by collecting secondary data from various sources. The study has employed value chain analysis which is very effective in tracing product flows, showing the physical value adding stages, qualitative and quantitative flow of product along the chain with identified key actors, their relationships with other actors in the chain and measured distribution of their benefits. This could be captured through mapping the value chain. Mapping the chain facilitates understanding of sequence of activities, key actors and relationship involved in the value chain. This analysis was undertaken in qualitative terms.

\section{Marketing margin}

According to Ghorbani (2008), marketing margin is important indices in the evaluation of value chain performance. It is the difference in the price paid by consumers and that received by the producers. Marketing margins are also calculated at different points along the value chain and then compared with consumer price. Once the basic structure of a marketing channel is established, it is relatively easy to collect information on the price at which the product is bought and sold at each stage in the production process (Smith, 1992).

Estimates of marketing margin are the best tools to analyses performance of market. The cost and price information used to construct marketing cost and margin have been gathered from head cabbage value chain actors such as, producers, collectors, retailers, wholesalers and consumers. Computing the total gross marketing margin (TGMM) is always related to the final price paid by the end buyer and is expressed as percentage (Mendoza, 1995).

TGMM $=\frac{\text { Consumer price-Farmers' } \text { price }}{\text { Consumer price }} \times 100$

(1)

Where: TGMM is total gross marketing margin

It is useful to introduce here the idea of producer participations, farmers portions or producers gross marketing margin (GMM) which is the portion of the price paid by the end consumer that belongs to the farmer as a producer. It should be emphasized that growers that as middlemen also receive an additional marketing margin. The producers' margin or share in the consumer price (GMMp) is calculated as:

$$
\mathbf{G M M p}=\frac{\text { Consumer price-Margin gross marketing }}{\text { Consumer price }} \times 100
$$

\section{GMMp= 1- TGMM}

Where, GMMp is = the producers share in consumer price

The net marketing margin (NMM) is the percentage of the final price earned by the intermediaries as their net income after their marketing costs are deducted. Thus the net marketing margin is calculated as:

$$
\mathbf{N M M}=\frac{\text { Gross marketing margin }- \text { marketing cost }}{\text { Consumer price }} \times
$$

\section{Results and Discussion}

This chapter presents the results of the study. Descriptive analysis is employed to describe the sociodemographic characteristics of sampled farm households, traders and consumers. Value chain analysis presents value chain analysis of head cabbage which includes value chain map, actors and their roles, value chain governance, challenges and opportunities along value chain, marketing channels, marketing costs and margins, and benefit shares of actors in the value chain discussed. Econometric analysis was employed to identify determinants of head cabbage market supply.

\subsection{Descriptive analysis}

Descriptive statistics of variables used in the regression analysis are given in Table 1 and 2 . As the study result revealed that from total quantity of the head cabbage produced only $33.48 \%$ proportion supplied to the market indicating low level of commercialization in the study area. This means the mean percentage of head cabbage harvested which was taken to the market for sale by the respondents in rural area was $33.48 \%$.

The average age of the sample respondents was found to be 37.33 years having head cabbage farming experience of 5.78 years. This range of households' ages implies most of them were within their productive age bracket. About $12.5 \%$ of households in the sample are female headed. The average household size is about 8.67 , with family labour supply of 4.4 persons per household, figures which are which is larger than the national average 4.6 persons per household (CSA, 2014b). Livestock owned 7.25 TLU. A household on average operates about 2.56 ha land of which 0.42 ha is allocated for head cabbage production, perhaps due to the availability of more arable farmland in the area. Almost $82.5 \%$ of household heads are literate, a figure which has shown significant rise in recent years. The extension services reached out $68.3 \%$ of the farm households, while the credit service extended only credit about $30 \%$. Though all the respondents in this survey are primarily engaged 
in crop production and livestock rearing, $56 \%$ of them are also participated in off/non-farm activities to generate additional income. Off/non-farm activities refers both to self-employments in non-farm sectors such as petty trade, craft work/carpentry, blacksmith, and off-farm employment such as cash/food for work (safety net), daily labor, and guard.

Table 3: Descriptive statistics of selected variables used in the empirical analyses

\begin{tabular}{|c|c|c|c|}
\hline Variables (Continues) & \multicolumn{2}{|l|}{ Mean } & Std. Dev. \\
\hline Age & \multicolumn{2}{|l|}{37.33} & 10.55 \\
\hline Family size & \multicolumn{2}{|l|}{8.67} & 3.34 \\
\hline Farming experience & \multicolumn{2}{|l|}{5.78} & 3.84 \\
\hline Livestock holding & \multicolumn{2}{|l|}{7.25} & 3.45 \\
\hline Farm size & \multicolumn{2}{|l|}{2.56} & 1.49 \\
\hline Land allocated for head cabbage & \multicolumn{2}{|l|}{0.42} & 0.32 \\
\hline Distance from nearest market center & \multicolumn{2}{|l|}{1.55} & 1.34 \\
\hline Variables (Dummy) & & Frequency & Percentage \\
\hline \multirow[t]{2}{*}{ Participation in non/off-farm income activities } & Yes & 67 & 55.83 \\
\hline & No & 53 & 44.17 \\
\hline \multirow{2}{*}{ Sex } & Male & 105 & 87.5 \\
\hline & Female & 15 & 12.5 \\
\hline \multirow[t]{2}{*}{ Education } & Literate & 99 & 82.5 \\
\hline & Illiterate & 21 & 17.5 \\
\hline \multirow[t]{2}{*}{ Credit services } & Yes & 36 & 30.0 \\
\hline & No & 84 & 70.0 \\
\hline \multirow[t]{2}{*}{ Extension services } & Yes & 82 & 68.3 \\
\hline & No & 38 & 31.7 \\
\hline \multirow[t]{2}{*}{ Market information } & Yes & 82 & 68.33 \\
\hline & No & 38 & 31.67 \\
\hline
\end{tabular}

\subsection{Head cabbage value chain actors and major functions}

The main actor involved in the head cabbage value chain, their roles and inter relationships are discussed below. Inputs suppliers

Agriculture value chain analysis begins at the input supply level. Inputs such as seeds, fertilizer, and chemicals are supplied by Union, Cooperative, Woreda Office of Agriculture (WoA), NGOs, traders at market and farmers to farmers exchange mechanism. Most (97\%) of the farmers were purchase seeds (Euro and Holland) from market for head cabbage production. Source of fertilizers were cooperatives $(67.26 \%)$, WoA $(22.12 \%)$ and market $(9.73 \%)$. The major suppliers of chemicals are private traders $(63.77 \%)$ from market, Union $(26.09 \%)$, agricultural office $(7.25 \%)$ and cooperative $(2.90 \%)$.

\section{Producers}

Farmers are the primary and most valued actor in the head cabbage value chain. Producers decide, what input to use, when to seed and harvest, how much to consume, and how much to sell, considering the available resource. They perform most of the value chain functions right from farm inputs preparation on their farms to post harvest handling and marketing. The major value chain functions that head cabbages producers perform include land preparation, growing/planting/, fertilization, protecting from weed, pest/disease, harvesting and post-harvest handling and marketing.

\section{Rural collectors}

Rural collectors are independent operators at primary markets who assemble and transport head cabbage from smallholder farmers, using pack animals and small trucks for sale to larger markets. The local traders play the key role as in the head cabbage value chain in area; their trading activities include buying and assembling, repacking, sorting, and selling to wholesalers typically transport on donkeys or cart to nearest town. Their major sales outlets are relatively rural collector. And most of these outlets own or rent storage but usually do not store for more than two or three days. These local traders collect head cabbage for wholesalers and wholesalers purchase from rural collectors by covering all cost and also additional fee for their services.

\section{Brokers/middle men}

Brokers in the districts have regular and temporary customers from major towns and cities across the country. Brokers facilitate transaction by convincing farmers to sale his head cabbage and facilitating the process of searching good quality and quantity head cabbage to wholesalers. The share of profit that goes to brokers varies from farmer to farmer and from trader to trader. The brokers sometimes go beyond facilitation of transaction and tend to set prices and make extra benefits from the process. A few wholesalers go straight to farmers' fields without using brokers to purchase the head cabbage products from the farmers where they negotiate prices. 
Brokers do not follow proper business conduct and as a result they constrain the marketing system more than they facilitate. In case the producer is not sold through broker, they forced to sell at the lower price because of perishability of the product. The broker travel to the rural areas and contact producers, they inspect the product quality, estimate output, set price and come back to communicating with wholesalers to purchase and transport. The farmers have no idea of the price paid by the wholesalers and only receive what has been bargained with the broker.

\section{Wholesalers}

Wholesalers are traders that buy head cabbage from rural collectors and also directly from farmers, usually those in surplus areas for resale in deficit, to larger market centers and retailers with better financial and information capacity. Wholesalers are the second major buyers of head cabbage as they buy at least a truck load of head cabbage at a time from farmers. They mostly purchase from farmers and local collectors. Wholesalers are traders that buy head cabbages from rural collectors and also directly from producer farmers of Kofele \& Kore districts and sell to retailers and consumers at Kofele, Kore, Shashemene and Hawassa markets. Wholesalers buy head cabbage from producers through brokers who represent them in head cabbage buying activities. They have better storage, transport and communication access than other traders.

\section{Retailers}

Retailers are key actors in head cabbage value chain within and outside the study area. These are known for their limited capacity of purchasing and handling products and low financial and information capacity. They are the last link between producers and consumers. There are two types of retailers in the study area districts retailers and central retailers. Districts retailers are buying head cabbage either from farmers or wholesale traders. While central (urban) retailers in major cities mostly they buy from wholesalers and sell to urban consumers. The supermarket and shops are mainly in the major cities and commonly buy head cabbage from wholesalers. During the market visit, it was observed that retailers keep small amount of head cabbage. Consumers usually buy the product from retailers as they offer according to requirement and purchasing power of the buyers.

\section{Consumers}

Consumers are final purchasers of head cabbage products mostly from retailers for consumption purpose. Head cabbage consumers are individual households (rural and urban dwellers) hotels and institutions. The majority of sampled consumers preferred undamaged and clean head cabbage. Consumers think that if the chain becomes shorter and shorter the price of head cabbage will be reduced.

\section{Enablers and facilitators}

In a value chain, enablers include all chain-specific actors providing regular support services or representing the common interest of the value chain actors. The supporting function players for the head cabbage value chain are those who are not directly related to the head cabbage value chain but provide different supports to the value chain actors. The support functions include different services (e.g. credit), research and development, infrastructure, and information. Support service providers are essential for value chain development and include sector specific input and equipment providers, financial services, extension service, and market information access and dissemination, technology suppliers, advisory service, etc. In the study areas, there are many institutions supporting the head cabbage value chain in one way or another. The most common support providers are District Agriculture Office, District Trade and Market Development Office, Cooperatives, Oromia Micro Finance Institutions, and Private transporters. Some service providers extend services beyond one function and others are limited to a specific function.

\subsection{Value chain map of head cabbage in the study area}

Mapping a value chain facilitates a clear understanding of the sequence of activities and the key actors and relationships involved in the value chain. Mapping of value chain functions is considered to show the relationships and integrations of the processes and activities performed along the value chain. Major functions include input supply, production, trading, processing and consumption. Figure 2 displays the functions or processes in head cabbage value chain map. 


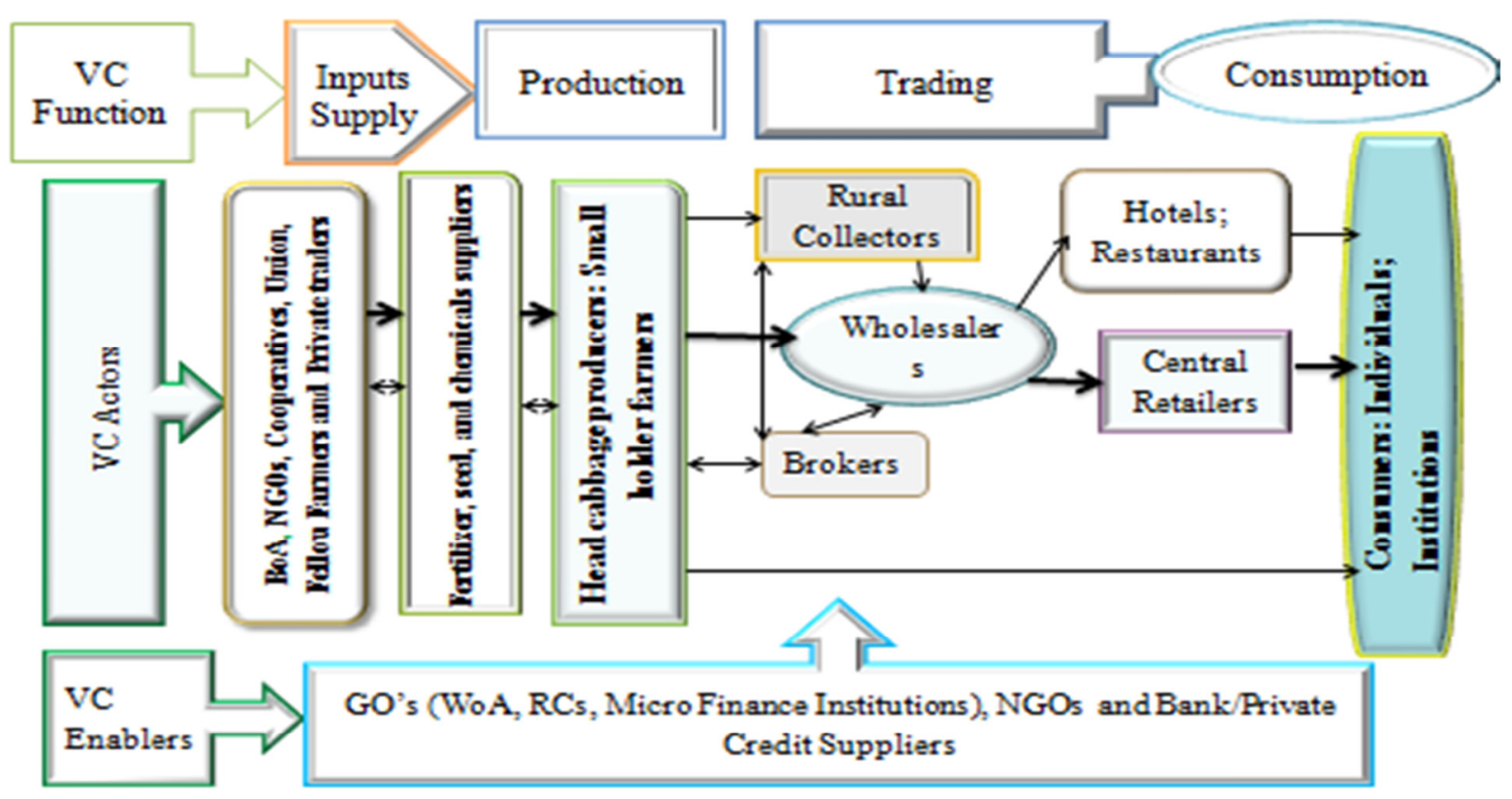

Figure 2: Value chain map of head cabbage in the study area Source: Sketch from survey result, 2014.

\subsection{Marketing Channels and Marketing Margin of head cabbage Head cabbage marketing channel}

Head cabbage market performance was evaluated based on the level of marketing margins obtained and considering associated marketing costs for each key market channels. Accordingly, during the study time costs and purchase prices of the main chain actors', margins at farmers', collectors, wholesalers, urban retailers and consumers' level were analyzed. Of total respondents farmers $65 \%$ sold head cabbage to wholesalers, $31.67 \%$ to retailers and $3.33 \%$ to collectors.

Marketing channel and marketing margins were used in the analysis of supply chain performance. Four parameters are necessary to measure the efficiency of a channel. These are quantity handled, producers share, total marketing margin, and rate of return. Out of these volumes handled, producers share and marketing margin were considered for all the head cabbage in this study. Consequently effectiveness is defined as the ability of the marketing channels to result to (or offer) proper service outputs or the right services in relation to consumer preferences. In essence therefore, identification of the marketing chain precedes its analysis. Marketing channels are defined as alternative routes of product flows from producers to consumers, (Kohls and Uhl, 1990). According to Adugna (2009), a marketing channel involves a series of intermediaries through which vegetables pass from producers to consumers. Five marketing channels of head cabbage are exhibited in the study areas. It was estimated that 6023 quintals of head cabbage were supplied to market by sampled farmers. Rural collectors and Wholesalers were the main receivers of head cabbage with percentage shares of $67.13 \%$ and $26.56 \%$, respectively (Figure 3). The market channels identified during the survey were:

Channel I: Producer--->Consumer

Channel II: Producer--->Rural collector--->Wholesaler--->Central retailer--->Consumer

Channel III: Producer---->Wholesaler--->Consumer

Channel IV: Producer--->Wholesaler--->Central retailer--->Consumer

Channel V: Producer--->Wholesaler--->Processor--->Consumer 


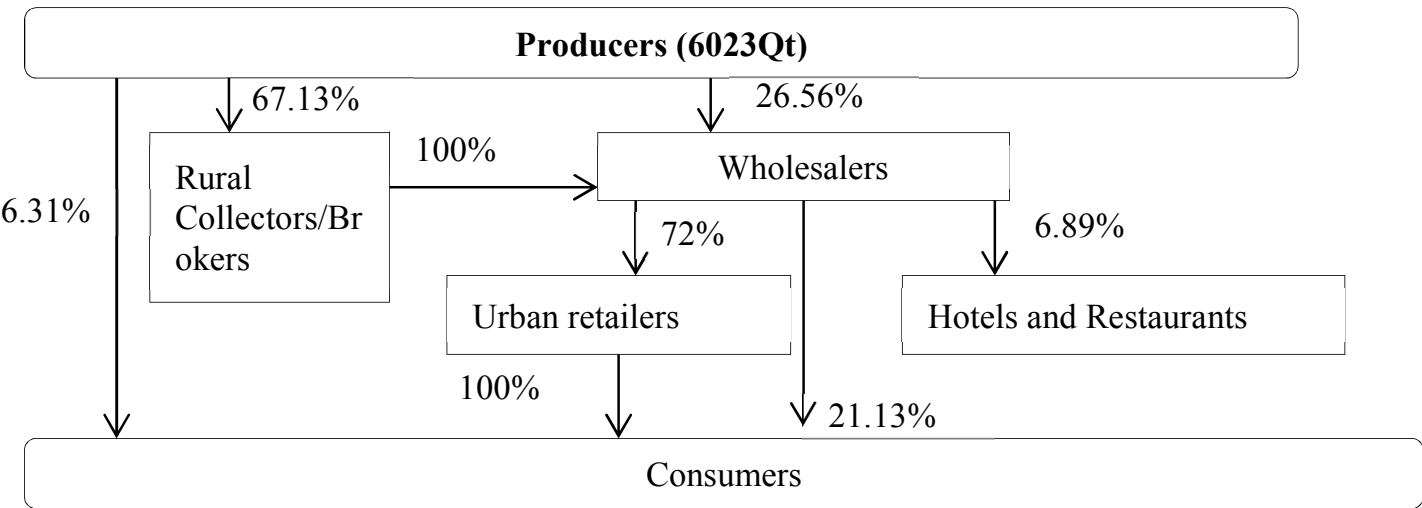

Figure.3: Head cabbage marketing chain in Kofele and Kore districts.

Source: Survey Data (2014).

\section{Marketing margins of head cabbage}

Margin determination surveys should be conducted parallel to channel surveys based on price (payment) received or selling price to calculate the margin. A systematically recording of prices at different levels of marketing chain during a two to three week period is sufficient to calculate quite accurately the relevant marketing margins (Pomeroy and Trinidad, 1995). Total gross marketing margin (TGMM) across complete distribution channel was $23.02 \%$ in both Kofele and Kore districts.

Tables 10 and 11 depict that buying and selling prices and marketing margins of different actors of head cabbage in each district. In Kofele, average purchase price $\left(\mathrm{P}_{1}\right)$ was ETB 981/quintal while the average selling price $\left(\mathrm{P}_{2}\right)$ was EBT 1356/quintal. In Kofele, head cabbage supplier farmers obtained the highest marketing margins by selling directly to consumers while the lowest is obtained from wholesalers (Table 10). The same is true for Kore district where head cabbage supplier farmers obtained the highest marketing margins by direct sell to consumers (Table 11). These differences in margins indicate that head cabbage market suitability varies across the districts which are in line with the findings of (Bonabana-Wabbi, 2014). These variations mainly occur due to marketing channels through which head cabbage passes and price differences across the district.

Head cabbage suppliers received the highest margins by selling head cabbage to consumers in both Kofele and Kore districts given the prevailing market prices. However, the volume of head cabbage supplied to rural collectors was high compare to wholesalers and consumers. The reason was due to shortage of transportation and high perishable nature of the products which needs immediate market. Head cabbage supplier farmer's shares low marketing margins (9.79\%) from wholesalers while high marketing margins $(33.55 \%)$ from consumers in Kofele district. In Kore, the highest and lowest farmer's margin shares were from consumers and wholesalers respectively. In both districts, the higher volume of head cabbages sold to rural collectors and wholesalers brought lower margin while the lower volume of head cabbages sold to consumers received higher margin. This implies that head cabbage supplier farmers had received higher marketing shares (margins) when they supply their products to consumers and as the channel increases farmers share is reduced in the study area. This result may point to the need for improving farmer's supply of their products to consumers through strengthening their linkage and delivering timely and adequate market information in the study areas. Outsourcing bulk consumers may also provide the opportunity to uptake bulk production with reasonable price.

Table 10: Head cabbage marketing margins for producers in Kofele district

\begin{tabular}{lllllllll}
\hline Actor & $\mathbf{Q}_{\mathbf{1}}$ & $\mathbf{P}_{\mathbf{1}}$ & $\mathbf{P}_{\mathbf{2}}$ & $\mathbf{Q}_{\mathbf{2}}$ & $\mathbf{V}_{\mathbf{1}}$ & $\mathbf{V}_{\mathbf{2}}$ & $\mathbf{V}_{\mathbf{2}}-\mathbf{V}_{\mathbf{1}}$ & $\mathbf{G M M}(\mathbf{\%})$ \\
\hline Rural collectors & 2179 & 1630 & 2236 & 1839.59 & 3551770 & 4113323 & 561553 & 13.65 \\
Wholesalers & 1483 & 1083 & 1422 & 1252 & 1606089 & 1780350 & 174261 & 9.79 \\
Consumers & 63 & 230 & 410 & 53.19 & 14490 & 21806.7 & 7316.65 & 33.55 \\
Average prices & & 981 & 1356 & & & & & \\
Percentage loss & 0.16 & & & & & & & \\
\hline
\end{tabular}

Table 11: Head cabbage marketing margins for producers in Kore district

\begin{tabular}{lllllllll}
\hline Actor & $\mathbf{Q}_{\mathbf{1}}$ & $\mathbf{P}_{\mathbf{1}}$ & $\mathbf{P}_{\mathbf{2}}$ & $\mathbf{Q}_{\mathbf{2}}$ & $\mathbf{V}_{\mathbf{1}}$ & $\mathbf{V}_{\mathbf{2}}$ & $\mathbf{V}_{\mathbf{2}}-\mathbf{V}_{\mathbf{1}}$ & $\mathbf{G M M}(\mathbf{\%})$ \\
\hline Rural collectors & 1281 & 1114 & 1435 & 1099.82 & 1427034 & 1578242 & 151208 & 9.58 \\
Wholesalers & 434 & 416 & 530 & 372.62 & 180544 & 197487 & 16942.7 & 8.58 \\
Consumers & 563 & 485 & 630 & 483.37 & 273055 & 304523.70 & 31468.70 & 10.33 \\
Average prices & & 671.67 & 865.00 & & & & & \\
Percentage loss $=$ & 0.14 & & & & & & & \\
\hline
\end{tabular}




\section{Conclusion and Recommendation}

A multi-stage sampling procedure was used to select 120 sampled households for data collection. The data were generated from both primary and secondary sources. The primary data were collected from individual interview using pre-tested semi-structured questionnaire and checklist. The analysis was made using descriptive statistics and econometric model using STATA software. The findings of this study are summarized as follows;-

From total quantity of the head cabbage produced only $33.48 \%$ supplied to the market by farmers where as the remained consumed at home and damaged due to its high nature of perishability. Of the 120 interviewed head cabbage producing households, $87.5 \%$ were male headed households. The average ages of the sampled respondents were 37.33 years having 5.78 years of head cabbage farming experience. The average family size was 8.67 with family labour supply of 4.4 persons per household. Livestock owned 7.25 TLU. A household on average operates about 2.56 ha land of which 0.42 ha is allocated for head cabbage production, perhaps due to the availability of more arable farmland in the area. Almost $83 \%$ of household heads are literate. Households in the study area on average $1.55 \mathrm{~km}$ away from nearest market center. The extension services reached out $68.3 \%$ of the farm households, while the credit service extended only credit about $30 \%$. Of the 120 interviewed head cabbage producing households, $68.3 \%$ have access to market information and $55.83 \%$ participated in non/offfarm income activities in the study area.

The chain is governed mainly by rural collector with the assistance of brokers. Producers are price takers and hardly negotiate the price due to fear of post-harvest loss, in case the product is not sold. About five different market channels of head cabbage are also identified in the study area. The highest total gross margins were $79.28 \%$ in channel II. The highest gross marketing margin of producers markets channels are $85.56 \%$ in channel IV.

Strengthening the linkage/interaction among value chain actors, there is a need to change the outlook of actors, by developing ground rules that will bind the relationship between producers and traders. In particular, positive attitudes toward partnership, interaction, networking and learning need to be developed among main actors in the value chain. So the chain actors should work in an integrated way to improve production, reduce post-harvest losses, and to strengthen sustainable market linkage in the study areas. In additions to this, organizing (voluntarily) traders and producers and establish trustful and strong trade agreements between the two institutions is crucial to minimize unfair price created by brokers. With a strong relationship between traders and producers, searching for market information and dissemination will be crucial.

Finally, further studies on the value chain are recommended to identify best upgrading practices agreed by different chain actors so that a well-organized regional and national vegetable production and marketing can be implemented.

\section{Acknowledgements}

The interviewed farmers, traders and consumers receive deepest thanks to their honest and true interview. We are also thankful to enumerators for their commitment during data collection. We would also like to thank Oromia Agricultural Research Institute (OARI) for funding this research and Adami Tulu Agricultural Research Centre for execution of the study.

\section{Reference}

Adugna Gessesse. 2009. Analysis of Fruit and Vegetables Market Chains in Alamata Southern Zone of Tigray: The case of Onion, Tomato, and Papaya. MSc Thesis, Haramaya University, Haramaya, Ethiopia.

Baker, D. 2006. Agriculture Value Chains: Overview of Concepts and Value Chain Approach. Presentation Prepared for the FAO LDED Regional Workshop for Asia, Bangkok.

J. Bonabana-Wabbi, S. Ayo, B. Mugonola, D. B. Taylor, J. Kirinya and M. Tenywa, The performance of potato markets in South Western Uganda, J. Dev. Agri. Eco., Vol. 5(6), pp. 225-235, 2013.

Bezabih Emana, Amsalu Ayana, Tesfaye Balemi and Milkessa Temesgen. 2014. Scoping study on vegetables seed systems and policy in Ethiopia. Addis Ababa, Ethiopia.

Bezabih Emana, Mengistu Ketema, Mutimba, K.J. and Jemal Yousuf. 2015. Factors Affecting Market Outlet Choice of Potato Producers in Eastern Hararghe Zone, Ethiopia. Journal of Economics and Sustainable Development, 6(15):2222-2855.

CSA. 2013. Population projection of Ethiopia for all regions at wereda level from 2014 - 2017. The Federal Democratic Republic of Ethiopia, Central Statistical Agency (CSA), Addis Ababa.

CSA (Central Statistical Agency). 2014a. Agricultural sample survey 2013/2014: Report on area and production of major crops (private peasant holdings, meher season), Statistical Bulletin. Addis Ababa, Ethiopia.

CSA (Central Statistical Agency). 2014b. Agricultural sample survey 2013/2014: Volume IV- Report on land utilization (Private peasant holdings meher season). Statistical Bulletin number 446, Addis Ababa, Ethiopia.

Hailegiorgis, D.S. and Hagos, F. 2016. Structure and performance of vegetable marketing in East Shoa zone, Oromia Region, Ethiopia. Journal of Marketing and Consumer Research. 26:7-16.

Kohls, R.L. and Uhl, J.N. 1985. Marketing of Agricultural Product. Fifth Edition. McMillian Publishing 
Company, New York, USA.

Mendoza, G. 1995. A Primer on Marketing Channels and Margins. Lyme Rimer Publishers Inc., USA. 425p.

OoARD. 2013. Report on major agricultural activities. Oromia National Regional State, West Arsi Zone, Kofele District Office of Agriculture and Rural Development (OoARD), Kofele.

OoARD. 2013. Report on major agricultural activities. Oromia National Regional State, West Arsi Zone, Kore District Office of Agriculture and Rural Development (OoARD), Kore.

Ghorbani, M. 2008. The Efficiency of Saffron ${ }^{e e}$ s Marketing Channel in Iran. World Applied Sciences Journal, 4(4): 523-527.

Pomeroy, R.S. and Trinidad, A.C. 1995. Industrial Organization and Market Analysis: p217-238. In: G.J. Scott (eds.). Prices, Products, and People: Analyzing Agricultural Markets in Developing Countries. Lynne Reinner Publishers, Boulder, London.

Smith, D. 1992. Costs and Returns in Agricultural Marketing. Marketing and Agribusiness Development Paper. Department of Political Economy, University of Glasgow. Glasgow, Scotland. 67p.

T. Yamane, Statistics: An Introductory Analysis, 2nd Ed., Harper and Row, New York, 1967, pp. 919.

Umesh Rudrappa, 2014, Cabbage nutrition facts and health benefits; www.nutrition-and-you.com

UNIDO (United Nations Industrial Development Organization). 2009. Agro-Value Chain Analysis and Development. Working paper 3:34. Vienna International Centre, Vienna, Austria.

World Bank. 2013. Agri-Business in Africa: Removing Barriers to Regional Trade to Food Staples. Washington. 